\title{
Bisphenols and Leydig Cell Development and Function
}

\section{OPEN ACCESS}

Edited by:

David H. Volle,

Institut National de la Santé et de la

Recherche Médicale

(INSERM), France

Reviewed by:

Nicolas Chevalier,

Centre Hospitalier Universitaire de

Nice, France

Francesco Pallotti,

Sapienza University of Rome, Italy

*Correspondence:

Ying Zhong

yzhong8@yahoo.com

Ren-Shan Ge

r_ge@yahoo.com

tThese authors have contributed equally to this work

Specialty section

This article was submitted to Reproduction, a section of the journal

Frontiers in Endocrinology

Received: 04 January 2020

Accepted: 08 June 2020

Published: 31 July 2020

Citation:

Li X, Wen Z, Wang Y, Mo J, Zhong Y and Ge R-S (2020) Bisphenols and

Leydig Cell Development and

Function. Front. Endocrinol. 11:447.

doi: 10.3389/fendo.2020.00447

\begin{abstract}
Xiaoheng $\mathrm{Li}^{1+}$, Zina Wen ${ }^{2 \dagger}$, Yiyan Wang ${ }^{1}$, Jiaying Mo ${ }^{1}$, Ying Zhong ${ }^{2 *}$ and Ren-Shan $\mathrm{Ge}^{1 *}$
${ }^{1}$ Department of Obstetrics and Gynecology, The Second Affiliated Hospital and Yuying Children's Hospital, Wenzhou Medical University, Wenzhou, China, ${ }^{2}$ Chengdu Xi'nan Gynecology Hospital, Chengdu, China
\end{abstract}

Bisphenol $\mathrm{A}(\mathrm{BPA})$ is a ubiquitous environmental pollutant, mainly from the production and use of plastics and the degradation of wastes related to industrial plastics. Evidence from laboratory animal and human studies supports the view that BPA has an endocrine disrupting effect on Leydig cell development and function. To better understand the adverse effects of BPA, we reviewed its role and mechanism by analyzing rodent data in vivo and in vitro and human epidemiological evidence. BPA has estrogen and anti-androgen effects, thereby destroying the development and function of Leydig cells and causing related reproductive diseases such as testicular dysgenesis syndrome, delayed puberty, and subfertility/infertility. Due to the limitation of BPA production, the increased use of BPA analogs has also attracted attention to these new chemicals. They may share actions and mechanisms similar to or different from BPA.

Keywords: bisphenol, bisphenol analogs, Leydig cells, steroids, reproductive function

\section{INTRODUCTION}

Leydig cells (LCs) are a group of cells specifically located in the interstitium of the testis [see review (1)]. They secrete two important hormones: testosterone ( $\mathrm{T}$, androgen), which is an androgen, and insulin-like 3 (INSL3) [see review (2)]. There are at least two generations of LCs, namely fetal LCs (FLCs) and adult LCs (ALCs) (2). These two generations of LCs have different development processes and different functions (2). In fetuses, $\mathrm{T}$ and metabolically activated dihydrotestosterone (DHT) from T by $5 \alpha$-reductase is essential for the development of the male reproductive tract (3). Failure to synthesize $\mathrm{T}$ may cause abnormalities in the male reproductive tract, such as hypospadias and small penis [see review (4)]. Androgens are also essential for testis descent (4). INSL3 binds to its receptor in the gubernaculum and pulls the testis from the kidney position to the lower part of abdomen (5). Insl3 knockout in mice leads to cryptorchidism, indicating that it is important for testis descent $(6,7)$. Therefore, defects in FLCs may cause the fetal part of Testicular Dysgenesis Syndrome (TDS) (8). TDS was coined to refer to diseases such as cryptorchidism and hypospadias in neonates and testicular cancer, as well as decreased fertility in men with common fetal causes (9). Although the exact cause is unclear, the high incidence of male reproductive tract defects in male neonates has brought significant attention to children's health $(10,11)$. In adults, $T$ is essential for the onset of puberty, the maintenance of secondary sexual characteristics, the promotion of spermatogenesis, and the promotion of muscle health (4). INSL3 is essential for regulating bone metabolism in adult males (12) and acts as an anti-apoptotic factor against germ cell apoptosis (13).

There is increasing evidence that environmental pollutants can cause TDS, androgen deficiency, and infertility. A group of highly studied environmental chemicals comprises bisphenol A [2,2-bis (4-hydroxyphenyl) propane, BPA, Figure 1] and related compounds, such as bisphenol AF, AP, B, C, F, H, S, Z, and other similar chemicals (Table 1). 


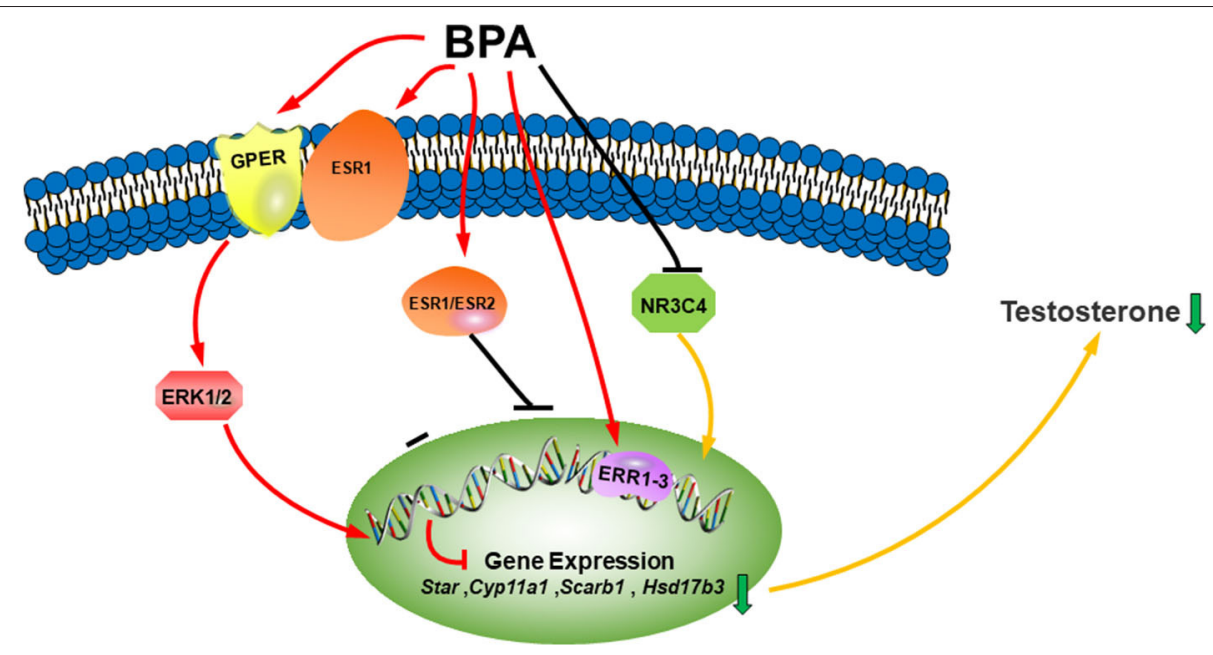

FIGURE 1 | Illustration of BPA on LC development. Bisphenol A (BPA) or its analogs can bind both estrogen receptors (ESR1 and ESR2) and estrogen-related receptors (ERR1-3), which blocks LC gene expression, binds to androgen receptor (NR3C4) as an antagonist to block the activation of LC genes. BPA can also bind membrane G-coupled receptor (GPER) or ESR1, which activates ERK1/2 pathway to inhibit the differentiation of Leydig cells. The combined consequence of BPA action leads to lower testosterone synthesis.

BPA is widely used in our industrial and consumer products and seriously pollutes our environment. BPA was first synthesized in 1891. Since then, BPA has been widely used in various products and applications as a common ingredient in plastic manufacturing. Plastics containing BPA are used to make children's toys, food containers, water bottles, medical equipment, and other durable materials (14-16). Many countries and regions are synthesizing BPA, including the United States, China, and European countries (16-19). Plastics are widely used in our consumer products and have changed our lifestyles, including the environment $(20,21)$. The widespread use of BPA-containing plastics has prompted BPA to spread in the environment. Therefore, BPA is ubiquitous in the environment, including air, drinking water, water systems, sewage sludge, soil, house dust, and food $(16,22)$. Humans are exposed to BPA mainly through food intake, dust, and skin contact $(14,15)$. BPA exposure through water and food is considered to be the main source $(16,22)$. Surveys indicate that $90 \%$ of urine samples in the general population of the United States can detect BPA levels $(14,17)$. The average urine BPA concentration in American people is about $2.5-10.95 \mathrm{ng} / \mathrm{ml}(14,17)$. BPA can also penetrate the placenta and enter the fetal circulation. The average level of BPA in pregnant women's plasma is $0.3-18.9 \mathrm{ng} / \mathrm{ml}$, and the average level of BPA in fetal plasma is $0.2-9.2 \mathrm{ng} / \mathrm{ml}(23,24)$, and the level of BPA in placental tissue is $1.0-104.9 \mathrm{ng} / \mathrm{g}$. BPA can enter breast milk, and the BPA level in breast milk is $0.28-$ $0.97 \mathrm{ng} / \mathrm{ml}(23,24)$. After ingestion through the oral route, BPA rapidly combines with blood proteins, and the concentration of free BPA in the blood is about $1 \mathrm{ng} / \mathrm{ml}$ (15).

There is increasing evidence that BPA is associated with the occurrence of reproductive toxicity $(25,26)$ and other health problems such as diabetes (27), neurotoxicity (28-30), immunotoxicity (31), and cancer (32-34).
BPA is classified as an endocrine disruptor that mainly mimics the effects of estrogen and disrupts the synthesis of male androgens (35-37). BPA is one of the most studied endocrine disrupting compounds. The toxicological effects of BPA may cause TDS (38) and other reproductive toxicities. The relationship between BPA and TDS and other reproductive effects has been well-studied in human epidemiology (18, 19, $39,40)$. Due to the reproductive toxicity of BPA, some new BPA analogs, such as bisphenol AF, AP, B, C, F, H, S, and Z, were introduced into the market (Table 1) (41-43). These new compounds have received little attention. Many data on BPA reproductive toxicity have been collected from mice and rats. In this review, we mainly discuss the effects of BPA and its analogs on the development and function of LCs.

\section{ACTION OF BPA}

\section{Estrogen Receptors}

The classic mechanism of estrogens requires them to bind to estrogen receptor (ESR), a type of nuclear receptor (44). There are two subtypes of ESR, namely ESR1 and ESR2 $(45,46)$. Estrogen binds to ESR to form a nuclear ESR dimer that binds to the ligand. This dimer binds to the DNA sequence (GGTCACAGTGACC) and is called an estrogen response element (ERE) in the target gene promoter to induce ESR transactivation (44). ESRs bind to the same sets of ERE in the target genes (47). When different isoforms exist in the same cell, the ESR bound to the ligand can form homodimers or heterodimers.

In addition to the genomic pathway of ESR, cytoplasmic/membrane-bound ESR interacts with many other proteins to mediate the activation of several kinase pathways that are hormone-dependent (48). 
TABLE 1 | Bisphenol analogs and their structures.

\begin{tabular}{|c|c|c|c|c|}
\hline Bisphenols & Abbreviation & CAS No. & MW & Structure \\
\hline Bisphenol AF & BPAF & $1478-61-1$ & 336.23 & \\
\hline Bisphenol AP & BPAP & $1571-75-1$ & 290.36 & \\
\hline Bisphenol B & BPB & $77-40-7$ & 242.31 & \\
\hline Bisphenol C & BPC & 14868-03-2 & 281.13 & \\
\hline Bisphenol E & BPE & $2081-08-5$ & 12.24 & \\
\hline Bisphenol F & BPF & $620-92-8$ & 200.24 & \\
\hline Bisphenol P & BPP & $2167-51-3$ & 346.50 & \\
\hline Bisphenol S & BPS & $201-250-5$ & 250.27 & \\
\hline Bisphenol Z & $\mathrm{BPZ}$ & $843-55-0$ & 268.35 & \\
\hline 4,4'-Thiodiphenol & TDP & 2664-63-3 & 218.27 & \\
\hline Tetramethyl bisphenol A & TMBPA & $5613-46-7$ & 284.39 & \\
\hline
\end{tabular}


Estrogen-related receptors $\alpha, \beta$, and $\gamma(\operatorname{ERR} \alpha, \operatorname{ERR} \beta$, and ERR $\gamma$, also known as ERR1-3) are another subfamily of orphan nuclear receptors with sequence similarity to ESR1 (49). However, $17 \beta$-estradiol (E2) is not its natural ligand, and ERR has constitutive activity (50). ERRs contain a DNA binding domain with two highly conserved zinc finger motifs in a specific DNA binding element (TCAAGGTCA, called ERRE). ERR and ERRE are combined into monomers or homodimers or heterodimers with coactivators (51). In addition to ERRE, ERR can also be bound to ERE. ESR1, but not ESR2, can also be combined with ERRE (52), so ESR1 and ERRs will affect each other.

In addition, estrogen can bind to $G$ protein-coupled membrane estrogen receptor (GPER, also known as GPR30), which is a member of the $G$ protein receptor superfamily. This receptor mediates the rapid signaling of estrogen. After activation, estrogen can induce ERK1/2 activation by releasing HB-EGF through transactivation of EGFR (53). GPER works through a pertussis toxin-sensitive pathway that depends on G $\beta \gamma$ (53). Then, GPER activation through G $\alpha$ s protein activation (54) stimulates adenylate cyclase, increases cAMP, and weakens the EGFR-MAPK signaling axis (55). The activation of cAMP further leads to the activation of PKA-CREB signal (56, 57 ) and the transcriptional activation of CREB. GPER also activates other signaling, including PI3K (58), PKC (59), and calcium (60).

\section{Estrogen Receptors in LCs}

In rodents, there are two generations of LCs: namely, FLCs and ALCs (2). The two generations of LCs have different development trajectories and functions $(2,61)$. The first generation of FLCs was found in fetal age (GD) 12 of mice, GD14 in rats, and fetal testes of human around gestational age (GW) $6(62,63)$. After birth, FLCs involute, and a few FLCs persist in the adult testes $(64,65)$.

The second-generation ALCs begin to develop around the 9th day after birth (PND) in rats, transit to progenitor LCs in PND21 (pre-pubertal period), develop into immature LCs during PND28-35, and finally mature to ALCs around PND56 (66).

ESRs, ERRs, and GER are differently expressed in LCs during the development, depending on two generations of LCs and species. ESR1 has been detected in mouse (67) and rat (68) FLCs, as well as mouse (69) and rat (70) ALCs. ESR2 was also found in mouse and rat (71) FLCs as well as mouse and rat (72) ALCs. It has been shown that the GPER level of rat LC is higher (73). In human fetal testes, ESR1 and ESR2 are located in FLCs $(74,75)$. Human LCs also have low levels of ESR1 and ESR2 and high levels of GPER (76-78). All three ERRs are found in mouse tumor LCs (79). In ESR1 knockout mice, ALCs are hypertrophic and serum $\mathrm{T}$ levels are elevated $(80,81)$. However, the ESR2 knockout mice did not change, but the average cell volume of ALC decreased (81).

\section{The Action of BPA and Its Analogs via Estrogen and Estrogen-Related Receptors in LCs}

Both FLCs and ALCs mainly synthesize $\mathrm{T}$ from steroid cholesterol. High-density lipoprotein transport through scavenger receptor class B member 1 (SCARB1) contributes to the formation of most cholesterol in LCs $(82,83)$. Under the stimulation of luteinizing hormone (LH) or human chorionic gonadotropin (hCG) by binding to LH receptor (LHCGR) on the surface of LCs, adenylate cyclase is activated to increase intracellular adenosine $3^{\prime}, 5^{\prime}$ cyclic monophosphate (cAMP) levels, triggering protein kinase A signaling (84). Then, the expression and phosphorylation of steroidogenic acute regulatory protein $($ StAR) is activated $(85,86)$ and, together with the translocation protein (TSPO) (87), they transport cholesterol to the mitochondrial inner membrane. In this organelle, there is a complex of P450 cholesterol side chain cleavage enzyme (CYP11A1), which catalyzes the production of pregnenolone by cholesterol (88). Pregnenolone diffuses from the mitochondria to the smooth endoplasmic reticulum, where 3 $\beta$-hydroxysteroid dehydrogenase (HSD3B), $17 \alpha$ hydroxylase/17,20-lyase (CYP17A1), and 17 $\beta$ - hydroxysteroid dehydrogenase 3 (HSD17B3) catalyzes a chain-reaction to generate $\mathrm{T}(89)$.

INSL3 is encoded by Insl3 in LCs and is secreted into the circulatory system $(6,90)$. Insl3 is also only expressed by two types of LCs. Insl3 encodes a G protein, a leucinerich repeat sequence GPCR 8 (also known as relaxin family peptide receptor 2, RXFP2). Knockdown of INSL3 or RXFP2 resulted in failure of testis descent (90-92), indicating that INSL3 is critical for testis descent. INSL3 constitutive expression depends only on LC number, but also on differentiation status. INSL3 is different from $\mathrm{T}$. When $\mathrm{T}$ synthesis is low, it is restored to normal levels by supplementing $\mathrm{LH}$ levels (93). Because INSL3 is specifically expressed by LCs, INSL3 is a powerful sensitive biomarker that is affected by environmental endocrine disruptors even when exposed to them during pregnancy (94).

The detailed mechanisms of BPA and its analogs to interfere with LC functions has been reviewed (95). When ESR1 was used to compare the estrogen potency of BPA with E2 through the endogenous estrogen regulatory gene in human MCF7 cells, the potency of BPA was found to be four to six orders of magnitude lower than E2 (96). Some of these studies have shown that the BPA analog BPS has lower estrogen potency than E2 when measured in nuclear receptor models. However, BPS has the same or higher estrogen potency as E2 by binding membrane ESR [see review (95)].

In mouse MLTC-1 tumor LCs, BPA, and E2 have similar potency and can inhibit LH-stimulated cAMP production with $<0.7 \mathrm{nM}$ after $1 \mathrm{~h}$, which may be caused by GPER (97).

Mouse tumor LCs express ERRs (79). BPA significantly binds to human ERR3, with an $\mathrm{IC}_{50}$ value of $13.1 \mathrm{nM}$, and binds to the ERR3 receptor cavity, and its two $\mathrm{OH}$ groups form a hydrogen bond; one forms a hydrogen bond with Glu275 and Arg316, and the other binds to Asn346 (98). BPA and ERR3 effectively bind as antagonists (28), and may inhibit cAMP-induced Star promoter activation by inhibiting the transcriptional activity of Nur77 (99). These results indicate that BPA works by binding different receptors, depending on the concentration. High concentrations of BPA mainly target 
ESR1, while low concentrations of BPA mainly target GPER and ERR3.

\section{Direct Inhibition on LC Steroidogenic Enzymes}

Besides the receptor-mediated actions, BPA also directly interferes with androgen synthesis. The direct effects of BPA on rat and human $\mathrm{T}$ synthetic enzymes, including CYP17A1, HSD3B, and HSD17B3, were evaluated using testis microsomes. BPA directly inhibited rat and human CYP17A1, HSD3B, and HSD17B3 enzyme activities. $\mathrm{IC}_{50}$ values of BPA for rat and human testicular HSD3B were about 27 and $8 \mu \mathrm{M}$; $\mathrm{IC}_{50}$ values for rat and human CYP17A1 were about 65 and $19 \mu \mathrm{M}$, and BPA inhibited both rat and human HSD17B3 around $100 \mu \mathrm{M}$ (100). Adult rat LCs also express both HSD11B1 and HSD11B2 (101), behaving in oxidative inactivation of cortisol or corticosterone, which can suppress androgen synthesis (102). BPA inhibited human HSD11B1, with an $\mathrm{IC}_{50}$ of about $15 \mu \mathrm{M}$ and rat enzyme with $\mathrm{IC}_{50}$ of about $19 \mu \mathrm{M}$. BPA also weakly inhibited both human and rat HSD11B2 with $\mathrm{IC}_{50}$ values about 100 or over $100 \mu \mathrm{M}$ (103). These results indicate that BPA directly inhibits steroidogenic enzyme activities at the higher concentrations.

\section{Other Mechanisms of BPA}

Studies using Nr3c4 (androgen receptor) knockout mice (104, $105)$ and Tfm mice $(106,107)$ showed that androgen is very critical for LC development. Knockout of Nr3c4 in Sertoli cells, LCs, and peritubular myoid cells $(104,105)$ also caused the delay of ALC development. BPA might act as antiandrogen via blocking the activation of NR3C4. Lee et al. used a yeast detection system for the antiandrogenic effects of BPA and found that BPA antagonized DHT binding at $50 \mathrm{nM}$ (108).

BPA-induced reactive oxygen species (ROS) generation has also been proposed for BPA-mediated suppression of $\mathrm{T}$ synthesis in LCs. ROS has been shown to disrupt LC steroidogenesis (109, 110). BPA was orally administered to adult male rats at $0.005,0.5,50$, and $500 \mu \mathrm{g} / \mathrm{kg} / \mathrm{day}$ for 45 days, and it significantly increased testicular ROS levels, suggesting that BPAinduced ROS might also be involved in its inhibition of $\mathrm{T}$ synthesis in LCs (111). Rats were administered BPA via gavage at $10 \mathrm{mg} / \mathrm{kg} /$ day BPA for 14 days, and it lowered $\mathrm{T}$ levels and decreased testis weight and inhibited antioxidants (such as SOD2 and catalase) and co-treatment with an antioxidant (lipoic acid) was able to reverse it (112). Male adult rats were administrated via gavage of $200 \mathrm{mg} / \mathrm{kg}$ BPA for 4 weeks, and it inhibited serum $\mathrm{LH}$ and $\mathrm{T}$ levels after decreasing SOD, GPx, and GSH and increasing ROS generation and antioxidants can attenuate BPA-induced inhibition (113). Adult male Wistar albino rats (aged 3 months) were gavaged with 50, 500, and $1,000 \mu \mathrm{g} / \mathrm{kg}$ BPA and/or vitamin E (40 mg/kg) for 3 months, and BPA significantly lowered T levels, testis weights, and sperm count, and vitamin E could attenuate it (114). These results indicate that BPA at high or very high doses also increases ROS levels.

\section{ANIMAL STUDIES}

\section{Effect of in utero BPA Exposure on Male Reproductive Tract Development}

Reports on the effects of in utero BPA exposure on T production and male reproductive tract development are conflicting. This difference may be due to the dosage, developmental period, and species. Pregnant CD mice orally exposed to $50 \mu \mathrm{g} / \mathrm{kg} \mathrm{BW} /$ day BPA from GD16 to 18 and F2 male pups had an increase in AGD on PND3 (115) (Table 2).

However, other studies have shown that BPA inhibits $\mathrm{T}$ synthesis in fetal testes. Oral administration of BPA from GD1 to GD22 to pregnant rats inhibited $\mathrm{T}$ production in neonates (129). Pregnant Sprague Dawley rats were administered 4, 40, and $400 \mathrm{mg} / \mathrm{kg}$ BW BPA via gavage daily from GD12 to 21, and BPA dose-dependently reduced serum $\mathrm{T}$ levels and down-regulated the expression of Insl3 and $H s d 17 b 3$ and their proteins at 40 and $400 \mathrm{mg} / \mathrm{kg}$ and that of Lhcgr, Cyp11a1, and Cyp17a1 and their proteins at $400 \mathrm{mg} / \mathrm{kg}$ (26). BPA inhibited FLC proliferation at $400 \mathrm{mg} / \mathrm{kg}$ (26). Pregnant Sprague Dawley rats were administered $0.002,0.02,0.5,50$, or $400 \mathrm{mg} / \mathrm{kg} \mathrm{BW}$ or $0.001,0.01,0.1,1$, or 10 $\mu \mathrm{g} / \mathrm{kg} \mathrm{BW} 17 \alpha$-ethynyl estradiol (EE, as the positive control of ESR1 agonist) daily s.c. from GD11 to GD20. Gene microarray analysis in GD20 fetal testes revealed that BPA at $400 \mathrm{mg} / \mathrm{kg}$ and $\mathrm{EE}$ at $10 \mu \mathrm{g} / \mathrm{kg}$ significantly down-regulated the expression of FLC genes, including Scarb1, Star, Cyp11a1, Cyp17a1, and Svs5 (116), and they had similar down-regulation patterns, suggesting that BPA exerts ESR1-mediated inhibition of FLC function (116). High doses of BPA exert similar effects to $E_{2}$. Horstman et al. also exposed pregnant Sprague Dawley rats to 0.001 or $0.1 \mu \mathrm{g} / \mathrm{kg}$ $\mathrm{BW} /$ day $\mathrm{EE}$ or $0.02,0.5$, and $400 \mathrm{mg} / \mathrm{kg} /$ day BPA via s.c. from GD11 to GD20 and found that the highest concentration of EE and BPA down-regulated the expression of Star gene and proteins (117) (Table 2). These studies indicate that BPA may show different actions at low and high doses and it may mainly bind to ESR1 to take action at the high doses.

\section{Effects of in utero BPA Exposure on Postnatal Male Reproduction}

There are also conflicting reports about the effects of in utero BPA exposure on the production of $\mathrm{T}$ after birth. This difference may also be due to dose, duration of treatment, and species. Pregnant rats were orally administered with 4 or $40 \mathrm{mg} / \mathrm{kg}$ BW/day BPA from GD6 to PND20, and BPA did not affect AGD in PND21 male offspring. This study cannot conclude the inhibitory effect of BPA on T secretion (118). From GD7 to PND18, pregnant Long Evans rats were administered doses of 2, 20, and $200 \mu \mathrm{g} / \mathrm{kg}$ BW/day, which had no effect on AGD at PND2 and nipple retention at PND14 in male offspring, suggesting that low doses of BPA cannot cause TDS (119). Pregnant mice were exposed to $50 \mu \mathrm{g} / \mathrm{kg}$ BW/day BPA from GD16 to GD18, which increased AGD and prostate size and decreased epididymal weight without affecting testicular weight at PND3, 21, and 60 (115) (Table 2).

Pregnant CD-1 mice who were administered low doses of BPA ( 2 and $20 \mu \mathrm{g} / \mathrm{kg} /$ day) via gavage of from GD11 to GD17 had significantly lower relative testicular weight compared to 8 and 12 -week-old male mice without affecting serum T levels (120). 
TABLE 2 | Bisphenol A (BPA) and animal studies.

\begin{tabular}{|c|c|c|c|}
\hline Species & Regimen & Outcome & References \\
\hline \multicolumn{4}{|c|}{ In utero exposure on FLC development and function } \\
\hline CD mouse & po $50 \mu \mathrm{g} / \mathrm{kg} /$ day from GD16 to 18 & $\begin{array}{l}\text { Increase of AGD and decrease of epididymal weight without } \\
\text { affecting testicular weights at PND3 }\end{array}$ & $(115)$ \\
\hline SD rat & po $4-400$ mg/kg/day from GD12 to 21 & $\begin{array}{l}\text { Reduction of serum T levels and expression of } \mathrm{Lhcgr}, \mathrm{Ins} / 3 \text {, and } \\
\text { Hsd17b3 and FLC proliferation at } 40 \text { or } 400 \mathrm{mg} / \mathrm{kg}\end{array}$ & (26) \\
\hline SD rat & s.c. $0.002-400 \mathrm{mg} / \mathrm{kg} /$ day from GD11 to 20 & $\begin{array}{l}\text { Reduction of expression of Scarb1, Star, Cyp11a1, Cyp17a1, and } \\
\text { Svs5 at } 400 \mathrm{mg} / \mathrm{kg}\end{array}$ & $(116)$ \\
\hline SD rat & s.c. $02-400 \mathrm{mg} / \mathrm{kg} /$ day from GD11 to 20 & Reduction of expression of Star at $400 \mathrm{mg} / \mathrm{kg}$ & $(117)$ \\
\hline \multicolumn{4}{|c|}{ In utero exposure on postnatal LC development and function } \\
\hline SD rat & po 4 or $40 \mathrm{mg} / \mathrm{kg} /$ day form GD6 to PND20 & Effect on at PND21 and inconclusive effect on T synthesis & $(118)$ \\
\hline LE rat & po 2-200 $\mu \mathrm{g} / \mathrm{kg} /$ day from GD7 to PND18 & $\begin{array}{l}\text { No effect on AGD examined at PND2 and nipple retention at } \\
\text { PND14 }\end{array}$ & (119) \\
\hline CD mouse & po $50 \mu \mathrm{g} / \mathrm{kg} /$ day from GD16 to 18 & $\begin{array}{l}\text { Decrease in epididymal weight without affecting testicular weights } \\
\text { at PND21 and } 60\end{array}$ & $(115)$ \\
\hline CD mouse & po 2, $20 \mu \mathrm{g} / \mathrm{kg} /$ day from GD11 to 17 & $\begin{array}{l}\text { Reduction of relative testicular weights at PND56 and } 84 \text { without } \\
\text { affecting serum T levels }\end{array}$ & $(120)$ \\
\hline SD rat & po $0.0025-250$ mg/kg/day from GD6 to PND90 & Reduction of testis/epididymis weights only at $250 \mathrm{mg} / \mathrm{kg}$ & $(121)$ \\
\hline LE Rat & po $2.5-25 \mu \mathrm{g} / \mathrm{kg} /$ day from GD12 to PND21 & $\begin{array}{l}\text { Increase of LC number and reduction of LHCGR and HSD17B3 } \\
\text { and T secretion at PND90 }\end{array}$ & $(122)$ \\
\hline \multicolumn{4}{|c|}{ Neonatal exposure on postnatal LC development and function } \\
\hline SD rat & s.c. $0.002-97 \mathrm{mg} / \mathrm{kg} /$ day from PND0-9 & $\begin{array}{l}\text { No effect of preputial separation, T levels, and fertility rate on } \\
\text { PND10 and PND150 }\end{array}$ & $(123)$ \\
\hline LE rat & po $2.4 \mu \mathrm{g} / \mathrm{kg} /$ day from PND21 to 35 & Reduction of serum LH and T levels & $(124)$ \\
\hline \multicolumn{4}{|c|}{ Adult exposure on postnatal LC development and function } \\
\hline Swiss mouse & po $5-100 \mu / \mathrm{kg}$ BW/day from PND21 to 35 & $\begin{array}{l}\text { Reduction of absolute testis weights, seminal vesicle weight and } \\
\text { sperm counts and fertility rate }\end{array}$ & $(125)$ \\
\hline SD rat & po from PND21 for 56 days & Reduction of free $\mathrm{T}$ levels without affecting $\mathrm{LH}$ levels & $(126)$ \\
\hline Wistar rat & s.c. $20-200$ mg/kg BW BPA from PND21 for 42 days & $\begin{array}{l}\text { Inhibition of plasma T and LH levels and down-regulation of } \\
\text { Cyp11a1 and Scarb1 }\end{array}$ & $(127)$ \\
\hline SD rat & s.c. $1 \mathrm{mg} / \mathrm{kg}$ BW BPA at adulthood for 14 days & Decrease in plasma $\mathrm{T}$ level and increase in LH level & $(128)$ \\
\hline SD rat & po $10 \mathrm{mg} / \mathrm{kg}$ BW BPA at adulthood for 14 days & Reduction of serum $\mathrm{T}$ levels and testis weight & $(112)$ \\
\hline SD rat & po $0.005-500 \mu \mathrm{g} / \mathrm{kg}$ BW BPA at adulthood for 45 days & $\begin{array}{l}\text { the testis as well as HSD3B1, HSD17B3, and StAR protein levels } \\
\text { and T levels }\end{array}$ & $(111)$ \\
\hline
\end{tabular}

AGD, anogenital distance; GS, gestational day; LH, luteinizing hormone; PND, postnatal day; po, gavage; s.c., subcutaneous; T, testosterone.

Sprague Dawley pregnant rats were given 0.006, 0.025, 0.25, 2.5, 25 , and $250 \mathrm{mg} / \mathrm{kg} \mathrm{BW/day} \mathrm{by} \mathrm{oral} \mathrm{administration} \mathrm{from} \mathrm{GD6}$ to GD21, and their male pups were directly administered via gavage of the same doses of BPA from PND1 to PND90. BPA only suppressed the weight of testes and epididymis at a dose of 250 $\mathrm{mg} / \mathrm{kg}$ (121) (Table 2).

However, when pregnant CD-1 mice were given 0.1 , 1 , or 10 $\mathrm{mg} / \mathrm{kg}$ BPA BW/day by gavage and another plasticizer bis (2ethylhexyl)-phthalate (DEHP) from GD1 to GD21, and further, in the weaning period (PND1-21), the mixture down-regulated the Star expression and reduced sperm count in epididymis at PND42 (130). This effect may be confused by the addition of DEHP. In pregnant Long-Evans rats gavaged with $2.5-25 \mu \mathrm{g} / \mathrm{kg}$ BW/day from GD12 to PND21, BPA stimulated LC proliferation during prepuberty and increased the number of LCs at PND90, but down-regulated LHCGR and HSD17B3 and decreased T secretion by LCs (122) (Table 2). These different actions of BPA might be due to the doses of BPA.

\section{Effects of Neonatal and Prepubertal BPA Exposure on Postnatal Male Reproduction}

There are also conflicting reports on the effects of BPA exposure on postnatal $\mathrm{T}$ production and reproduction. This difference may also be due to dose, duration of treatment, and species. Male Sprague Dawley rats were daily s.c. administered 0.002-97

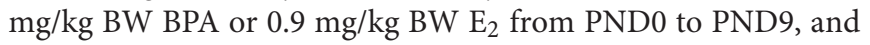
BPA did not affect preputial separation (an androgen-dependent process), T levels, and fertility rate on PND10 and PND150, while $\mathrm{E}_{2}$ inhibited these parameters (123). However, Long Even rats were orally exposed to $2.4 \mu \mathrm{g} / \mathrm{kg}$ BW/day BPA from PND21 to PND35, and BPA inhibited serum LH and T levels (124). Rats were exposed to $2.4 \mu \mathrm{g} / \mathrm{kg} \mathrm{BW} /$ day BPA from GD12 to PND21, and BPA inhibited T levels in adulthood (124). Prepubertal mice were administered BPA via gavage for 56 days, and they had significantly lower free $\mathrm{T}$ levels without a change in $\mathrm{LH}$ levels (126). Prepubertal Wistar male rats (28 days old) were injected subcutaneously with 20,100, and $200 \mathrm{mg} / \mathrm{kg}$ BW/day 
BPA, and BPA inhibited plasma T and LH for 6 weeks but did not affect FSH levels. BPA down-regulated steroidogenic enzymes and cholesterol carrier proteins in LCs and decreased LC number (127) (Table 2).

\section{Effects of Adult BPA Exposure on Male Reproduction}

Adult male Swiss mice were given BPA by gavage of 5, 25, and 100 $\mu \mathrm{g} / \mathrm{kg}$ BW for 28 days. BPA significantly lowered absolute testis weights, seminal vesicle weight, and sperm count and fertility rate (125). Adult male rats were exposed subcutaneously to 1 $\mathrm{mg} /$ rat BPA for 14 days. BPA decreased plasma $\mathrm{T}$ level and increased LH levels, suggesting that BPA directly inhibits LC function (128). Adult rats were administered via gavage of 10 $\mathrm{mg} / \mathrm{kg}$ BW/day BPA for 14 days. BPA lowered T levels, decreased testis weight, and inhibited antioxidants, and co-treatment with an antioxidant (lipoic acid) could reverse it (112). Adult male rats were administered by gavage of $0.005,0.5,50$, and $500 \mu \mathrm{g} / \mathrm{kg}$ BW/day BPA for 45 days. BPA significantly decreased insulin, insulin receptor, insulin receptor substrate-1, phosphoinositide 3-kinase (PI3K), and GLUT-2 in the testis as well as HSD3B1, HSD17B3, and StAR protein levels and T levels (131). Adult male rats were gavaged with 400 or $800 \mu \mathrm{mol} / \mathrm{kg}$ BW/day BPA for 14 days. BPA significantly decreased CYP17A1, POR, CYP1B1, and CYP2A1 protein levels without affecting HSD3B1 protein levels (132) and this potency of BPA was similar to $4 \mu \mathrm{mol} / \mathrm{kg} \mathrm{BW} /$ day $\mathrm{E}_{2}$ (132). Treatment of ALCs with $0.01 \mu \mathrm{M}$ BPA decreased $\mathrm{T}$ synthesis by down-regulating expression of Cyp17a1 (124) (Table 2). This further demonstrates that BPA has different effects depending on doses.

\section{HUMAN STUDIES}

\section{Human Epidemiological Study}

Some epidemiological studies have explored the relationship between human exposure to BPA during pregnancy and male reproductive diseases. The results are contradictory. Fénichel et al. measured unconjugated BPA levels in cord blood in 152 boys born after GW34 with cryptorchidism and 106 controls and did not find any association between BPA and cryptorchidism (133). Cord blood BPA levels were measured in 52 neonates with cryptorchidism and 128 controls in France. No correlation was found between BPA and $\mathrm{T}$ or cryptorchidism, but a significant negative correlation was found between BPA and INSL3 (18). Because INSL3 and T are important for testis descent, no relationship of BPA with cryptorchidism might be involved in more confounding factors. Serum BPA levels were detected in 98 (1-4 years old) unilateral cryptorchidism boys and 57 controls. No association between free BPA levels and cryptorchidism was found. However, they did find a significant association between total BPA levels and cryptorchidism (134). Fernandez et al. measured free BPA levels in term placenta in 28 boys of cryptorchidism/hypospadias and 51 controls, finding an association between BPA levels and cryptorchidism/hypospadias in the third tertile of cases (135). Miao et al. investigated maternal occupational exposure to BPA and AGD in 56 BPA-exposed male offspring and 97 unexposed controls and found that BPA was significantly negatively correlated with AGD (136). Liu et al. investigated the effect of BPA on sex hormone levels in 100 mother-infant pairs in two hospitals in China and found that maternal urinary BPA levels were negatively correlated with male fetal cord blood $\mathrm{T}$ levels and T/E2 ratios in male fetal cord blood without association with AGD (137). Therefore, more human studies are needed to clarify the effect of BPA on FLC functions of male fetuses and newborns.

For BPA-mediated effects on adult reproduction, Adoamnei et al. measured urinary BPA levels, serum LH levels, and sperm counts in 215 healthy young men (ages 18-23 years) in southern Spain, and found that urinary BPA was positively associated with serum LH levels and negatively with sperm concentrations, suggesting that BPA disrupts LC function and spermatogenesis (138). Den Hond et al. measured the urinary BPA levels and serum sex hormones in 163 subfertile men in four fertility clinics and found that there was a negative association between urinary BPA concentrations and serum T levels (139). Meeker et al. measured urinary BPA levels and serum reproductive hormone levels in 167 infertile men and found an inverse relationship between urinary BPA levels and free T (T/SBBG) (140). Mendiola et al. reported on 375 men with partners of pregnant women in four cities of the United States and found that urinary BPA level was not associated with semen quality, but was negatively related to free $\mathrm{T}$ index and positively related to SHBG (141).

\section{In vitro Studies Using Human Testis}

The effect of BPA on FLC function was evaluated in human fetal testes. Exposure of BPA to human GW6-11 fetal testis explants for 3 days did not affect $\mathrm{T}$ secretion at $1 \mathrm{nM}$, but significantly lowered $\mathrm{T}$ secretion at 10 and $10 \mu \mathrm{M}$ (142). Ben Maamar et al. found that BPA exposure to human GW7-12 human fetal testis explants for 3 days significantly inhibited $\mathrm{T}$ synthesis under the basal and LH or hCG-stimulated conditions at $10 \mu \mathrm{M}(143,144)$. BPA exposure also inhibited $\mathrm{T}$ secretion under a basal condition at $10 \mathrm{nM}$, but not under a LH-stimulated condition at this low concentration (143). Similar data were observed on the basis of BPA exposure to GW6-11 human testis and LH-stimulated T synthesis (41). Interestingly, Eladak et al. performed the first and second trimester human fetal testis xenograft to explore effect of BPA on T secretion and found that exposure of host mice to $10 \mu \mathrm{M}$ BPA in water or 0.5 or $50 \mu \mathrm{g} / \mathrm{kg} \mathrm{BPA}$ via gavage for 35 days did not influence $\mathrm{T}$ secretion from xenografts $(41,145)$.

\section{BPA ANALOGS}

\section{Exposure of BPA Analogs}

Due to strict restrictions on the production and use of BPA, several BPA analogs are gradually replacing BPA. Recent studies have reported that there was widespread exposure to a variety of chemicals with structural or functional similarity to BPA, referred to as BPA analogs (Table 1). BPA and its analogs were reported to exist in food stuffs $(16,146)$ and indoor dust $(147)$ in both China and the United States. BPS and BPF are highly detectable in many water supply systems (148) and paper (149). BPA analogs can enter human tissues, circulation, and urine. In a survey for 190 women in Hangzhou, China, showed that, 
besides BPA (average level of $2.5 \mathrm{ng} / \mathrm{mL})$, BPS $(0.19 \mathrm{ng} / \mathrm{mL})$ and BPAF $(0.092 \mathrm{ng} / \mathrm{mL})$ were also detectable in breast milk (150). In the serum samples of 181 Chinese pregnant women, BPS, BPF, BPAF, BPB, BPP, BPZ, BPAP, TBBPA, tetrabromobisphenol $\mathrm{S}$ (TBBPS), and tetrachlorobisphenol A (TCBPA) were detected, and TBBPS was $0.593 \mathrm{ng} / \mathrm{mL}$ and BPS was $0.113 \mathrm{ng} / \mathrm{mL}$ (151). $\mathrm{BPB}$ was detected in the urine of Portuguese volunteers, and its level was similar to BPA (152) (Table 1).

\section{In vitro Studies of BPA Analogs}

Despite extensive research on the effects and toxicity of BPA on the male reproductive endocrine system in mammals, including humans, little is known about the activity of most BPA analogs. Several studies have been conducted on the toxicological effects of certain BPA analogs on Leydig cell function.

As mentioned above, LCs contain NR3C4 and androgen agonists, and antagonists can affect their development and function. The effects of BPA, BPF, BPS, and tetrabromobisphenol (TBBPA) on the activation of human NR3C4 were studied in vitro. BPA, BPF, and TBBPA antagonized NR3C4 activation with IC $_{50}$ values of 39,20 , and $0.982 \mu \mathrm{M}$, while BPS did not affect it (153) (Table 3). Using a human recombinant androgen receptor (NR3C4) competitive binding test, it was found that BPB binds NR3C4 at a potency similar to BPA $(157,158)$. However, BPS bound NR3C4 weakly (157). BPA and its analogs were compared using in vitro and in vivo reporter assays for androgen agonism and antagonism. BPA significantly antagonized DHT androgenic activity in mouse fibroblast cell line NIH3T3 with TMBPA> BPAF $>$ BPAD $>$ BPB $>$ BPA, whereas TBBPA and TCBPA were inactive (159). In another assay, like BPA, the following BPA analogs, TBBPA, BPAF, BPB, BPZ, BPE, 4,4-BPF, 2,2-BPF, BPC, TGSA, and TMBPA were NR3C4 antagonists between 3 and $100 \mu \mathrm{M}$, where BPS and TCBPA were inactive (160).

A series of estrogen receptor luciferase assays of BPA analogs in all 127 test compounds showed that BPC bound ESR1 with the highest affinity, with $\mathrm{IC}_{50}$ of $2.81 \mathrm{nM}$, and other BPA analogs such as BPAF (53.4 nM), BPM (56.8 nM), BPZ (56.9 nM), BPP (176 nM), BPB (195 nM), BPAP (259 nM), and BPA (1,780 nM) (155) (Table 3). Estrogen receptor binding experiments have shown similar effects of these BPA analogs $(154,156)$ (Table 3$)$. Comparing the estrogen activity of BPA and its analogs in human breast cancer cell line MCF-7, the results showed that the estrogen activity was TCBPA $>$ BPB $>$ BPA $>$ TMBPA (159). Using an in vivo uterotrophic assay in ovariectomized mice, antiestrogenic activity against $E_{2}$ was observed with TMBPA and TBBPA (159).

Compared with ESR1, BPAF also binds to ESR2 more effectively. The $\mathrm{IC}_{50}$ value of BPAF for ESR2 as an antagonist is $18.9 \mathrm{nM}$. Reporter gene assay showed that BPAF is a full agonist of ESR1, inactive to ESR2, and has very weak binding to ERR3 (161).

In vitro studies showed that after $24 \mathrm{~h}$ of treatment, BPAF was found to dose-dependently inhibit the production of $\mathrm{P} 4$ in mLTC-1 tumor LCs after $24 \mathrm{~h}$ of treatment with an $\mathrm{IC}_{50}$ value of $70.2 \mu \mathrm{M}$. BPAF also lowered intracellular cAMP levels and down-regulated Scarb1 and Cyp11a1 expression without affecting Star expression (162). This indicates that at high concentrations, BPAF has similar effect to BPA.

When MA-10 tumor LCs were treated with BPA analogs, TBBPA induced $\mathrm{T}$ synthesis, while BPF and BPS increased P4 levels (153). Fetal human testis was exposed to BPA, BPF, and

TABLE 3 | Bisphenols as estrogen receptor agonists and androgen receptor (NR3C4) antagonists.

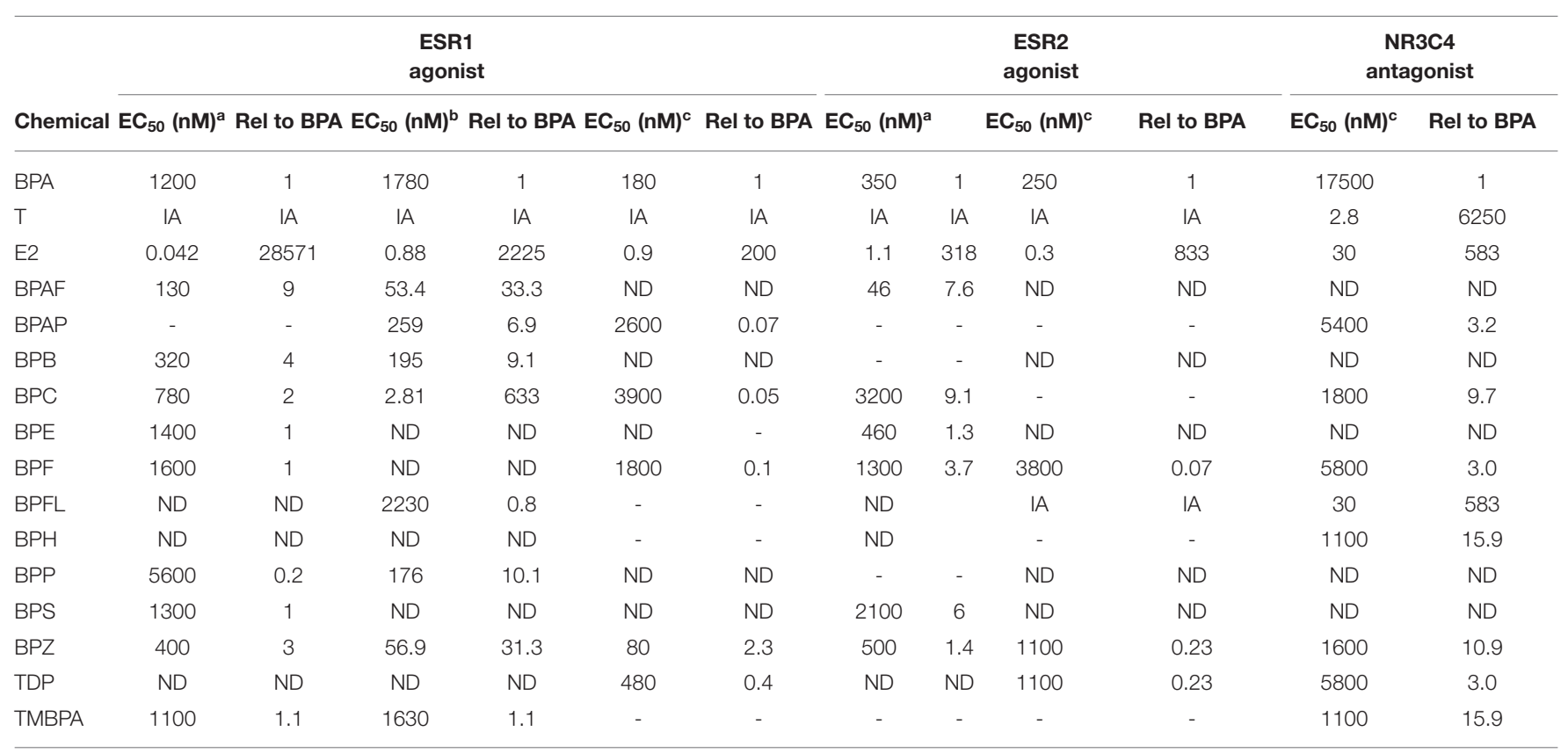

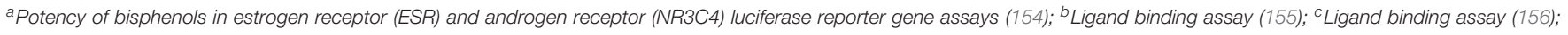
$I A$, inactive; ND, not detected; -, no active activity; REL, potency relative to BPA. 
BPS in vitro. These compounds inhibited T secretion at $10 \mathrm{nM}$ (41). Fetal mouse testis was exposed to BPA and its analogs; these chemicals inhibited $\mathrm{T}$ secretion at higher concentrations, and the minimum effective concentrations were $1 \mu \mathrm{M}$ for BPA and BPF as well as $100 \mathrm{nM}$ for BPS (41). These data indicate that there is species-dependent difference for the inhibition of $\mathrm{T}$ synthesis between humans and mice, and human is more sensitive to BPA analogs than mouse. These chemicals also lowered Insl3 transcription level at $10 \mu \mathrm{M}$ in fetal mouse testis (41).

\section{In vivo Studies of BPA Analogs}

Only some reproductive and developmental toxicity studies have been conducted on BPA analogs. BPAF did not change fetal $\mathrm{T}$ secretion from male fetuses on GD18 when exposed to BPAF by GD14 to 18 at a dose of $200-500 \mathrm{mg} / \mathrm{kg} /$ day (163). Exposure of rats to 5, 25, and $50 \mu \mathrm{g} / \mathrm{L} \mathrm{BPA}$ and its analogs $\mathrm{BPB}, \mathrm{BPF}$, and BPS from GD1 to GD21 in drinking water caused significantly low antioxidant enzyme, plasma testosterone, and estrogen concentrations and altered morphological changes of testis and epididymis in male offspring after birth (164). In vivo studies of $5 \mathrm{mg} / \mathrm{kg} /$ day of BPA, BPB, BPF, and BPS exposed to adult male rats for 28 days showed that they led to decreased $\mathrm{T}$ levels and increased ROS levels (165). Male prepubertal rats exposed to 5,25 , and $50 \mu \mathrm{g} / \mathrm{L} \mathrm{BPA}, \mathrm{BPB}, \mathrm{BPF}$, and BPS in drinking water for 48 weeks also showed a decrease in $\mathrm{T}$ levels in the highest dose group (166). These results indicate that BPA analogs BPB, BPF, and BPS have similar effects on the development of the male reproductive system to BPA.

\section{CONCLUSION}

BPA is a ubiquitous environmental pollutant, mainly from the manufacture and use of plastics and its degradation of

\section{REFERENCES}

1. Chen P, Zirkin BR, Chen H. Stem leydig cells in the adult testis: characterization, regulation and potential applications. Endocr Rev. (2020) 41:bnz013. doi: 10.1210/endrev/bnz013

2. Ye L, Li X, Li L, Chen H, Ge RS. Insights into the development of the adult leydig cell lineage from stem leydig cells. Front Physiol. (2017) 8:430. doi: $10.3389 /$ fphys.2017.00430

3. Li X, Mo J, Zhu Q, Ni C, Wang Y, Li H, et al. The structureactivity relationship (SAR) for phthalate-mediated developmental and reproductive toxicity in males. Chemosphere. (2019) 223:504-13. doi: 10.1016/j.chemosphere.2019.02.090

4. Wang Y, Ni C, Li X, Lin Z, Zhu Q, Li L, et al. Phthalate-Induced Fetal Leydig Cell Dysfunction Mediates Male Reproductive Tract Anomalies. Front Pharmacol. (2019) 10:1309. doi: 10.3389/fphar.2019.01309

5. Boockfor FR, Fullbright G, Bullesbach EE, Schwabe C. Relaxin-like factor (RLF) serum concentrations and gubernaculum RLF receptor display in relation to pre- and neonatal development of rats. Reproduction. (2001) 122:899-906. doi: 10.1530/rep.0.1220899

6. Adham IM, Emmen JM, Engel W. The role of the testicular factor INSL3 in establishing the gonadal position. Mol Cell Endocrinol. (2000) 160:11-6. doi: 10.1016/S0303-7207(99)00188-4

7. Feng S, Bogatcheva NV, Kamat AA, Agoulnik AI. Genetic targeting of relaxin and insl3 signaling in mice. Ann N Y Acad Sci. (2005) 1041:82-90. doi: 10.1196/annals.1282.012 waste related to industrial plastics. More and more animal experiments have shown that BPA has endocrine disruption to the development and function of LCs. Studies on laboratory animals have shown that the effect of BPA is usually more harmful in the uterus, which is a critical stage of embryonic development. BPA has been found to cause defects in the embryo, such as feminization of the male fetus, atrophy of the testes and epididymis, as well as shortened AGD and changes in adult sperm parameters. BPA also disrupts the development of LCs after birth and the function of LCs in adulthood. BPA may have several molecular mechanisms: (1) binding to different ESR (ERS1 and ERS2) and ERR (1-3) as agonists, and NR3C4 as antagonist (Figure 1); (2) binding to the membrane receptor (GPER) (Figure 1); (3) direct inhibition of steroidogenic enzyme activity; and (4) stimulation of ROS production. Epidemiological studies provide some data indicating that BPA can change male reproductive function in men. There are dose-dependent effects, including low-dose and high-dose effects and species-dependent effects. Human testes may be more sensitive to the $\mathrm{T}$ inhibition of BPA analogs.

\section{AUTHOR CONTRIBUTIONS}

$\mathrm{XL}$ and ZW wrote the paper. R-SG and YZ edited the paper. YW prepared the tables. JM draw the figure. All authors contributed to the article and approved the submitted version.

\section{FUNDING}

This work was supported by NSFC (81730042 to R-SG, and 81901467 to YW), Science and Technology Department of Zhejiang Province (2019C03035 to R-SG).
8. Hu GX, Lian QQ, Ge RS, Hardy DO, Li XK. Phthalate-induced testicular dysgenesis syndrome: Leydig cell influence. Trends Endocrinol Metab. (2009) 20:139-45. doi: 10.1016/j.tem.2008.12.001

9. Skakkebaek NE, Rajpert-De Meyts E, Main KM. Testicular dysgenesis syndrome: an increasingly common developmental disorder with environmental aspects. Hum Reprod. (2001) 16:972-8. doi: 10.1093/humrep/16.5.972

10. Carmichael SL, Yang W, Roberts EM, Kegley SE, Wolff C, Guo L, et al. Hypospadias and residential proximity to pesticide applications. Pediatrics. (2013) 132:e1216-1226. doi: 10.1542/peds.2013-1429

11. Fenichel P, Chevalier N, Lahlou N, Coquillard P, Wagner-Mahler K, Pugeat $\mathrm{M}$, et al. Endocrine disrupting chemicals interfere with leydig cell hormone pathways during testicular descent in idiopathic cryptorchidism. Front Endocrinol. (2018) 9:786. doi: 10.3389/fendo.2018.00786

12. Ferlin A, Pepe A, Gianesello L. Mutations in the insulin-like factor 3 receptor are associated with osteoporosis. J Bone Miner Res. (2008) 23:683-93. doi: 10.1359/jbmr.080204

13. Amory JK, Page ST, Anawalt BD, Coviello AD, Matsumoto AM, Bremner WJ. Elevated end-of-treatment serum INSL3 is associated with failure to completely suppress spermatogenesis in men receiving male hormonal contraception. J Androl. (2007) 28:548-54. doi: 10.2164/jandrol.106. 002345

14. Calafat AM, Ye X, Wong LY, Reidy JA, Needham LL. Exposure of the U.S. population to bisphenol A and 4-tertiary-octylphenol: 2003-2004. Environ Health Perspect. (2008) 116:39-44. doi: 10.1289/ehp.10753 
15. Vandenberg LN, Chahoud I, Heindel JJ, Padmanabhan V, Paumgartten FJ, Schoenfelder G. Urinary, circulating, and tissue biomonitoring studies indicate widespread exposure to bisphenol A. Environ Health Perspect. (2010) 118:1055-70. doi: 10.1289/ehp.0901716

16. Liao C, Kannan K. A survey of bisphenol A and other bisphenol analogues in foodstuffs from nine cities in China. Food Addit Contam Part A Chem Anal Control Expo Risk Assess. (2013) 31:319-29. doi: 10.1080/19440049.2013.868611

17. Lakind JS, Naiman DQ. Bisphenol A (BPA) daily intakes in the United States: estimates from the 2003-2004 NHANES urinary BPA data. J Expo Sci Environ Epidemiol. (2008) 18:608-15. doi: 10.1038/jes.2008.20

18. Chevalier N, Brucker-Davis F, Lahlou N, Coquillard P, Pugeat M, Pacini P, et al. A negative correlation between insulin-like peptide 3 and bisphenol A in human cord blood suggests an effect of endocrine disruptors on testicular descent during fetal development. Hum Reprod. (2015) 30:447-53. doi: 10.1093/humrep/deu340

19. Liang H, Xu W, Chen J, Shi H, Zhu J, Liu X, et al. The association between exposure to environmental bisphenol $\mathrm{A}$ and gonadotropic hormone levels among men. PLoS ONE. (2017) 12:e0169217. doi: 10.1371/journal.pone.0169217

20. Furhacker M, Scharf S, Weber H. Bisphenol A: emissions from point sources. Chemosphere. (2000) 41:751-6. doi: 10.1016/S0045-6535(99)00466-X

21. Safe S. Bisphenol A and related endocrine disruptors. Toxicol Sci. (2000) 56:251-2. doi: 10.1093/toxsci/56.2.251

22. Song S, Ruan T, Wang T, Liu R, Jiang G. Distribution and preliminary exposure assessment of bisphenol AF (BPAF) in various environmental matrices around a manufacturing plant in China. Environ Sci Technol. (2012) 46:13136-43. doi: 10.1021/es303960k

23. Schonfelder G, Wittfoht W, Hopp H, Talsness CE, Paul M, Chahoud I. Parent bisphenol A accumulation in the human maternal-fetalplacental unit. Environ Health Perspect. (2002) 110:A703-707. doi: 10.1289/ehp.110-1241091

24. Sun $\mathrm{Y}$, Irie $\mathrm{M}$, Kishikawa $\mathrm{N}$, Wada $\mathrm{M}$, Kuroda $\mathrm{N}$, Nakashima K. Determination of bisphenol A in human breast milk by HPLC with column-switching and fluorescence detection. Biomed Chromatogr. (2004) 18:5015507. doi: 10.1002/bmc.345

25. Wong EW, Cheng CY. Impacts of environmental toxicants on male reproductive dysfunction. Trends Pharmacol Sci. (2011) 32:290-9. doi: 10.1016/j.tips.2011.01.001

26. Lv Y, Li L, Fang Y, Chen P, Wu S, Chen X, et al. In utero exposure to bisphenol A disrupts fetal testis development in rats. Environ Pollut. (2019) 246:217-24. doi: 10.1016/j.envpol.2018.12.006

27. Soundararajan A, Prabu P, Mohan V, Gibert Y, Balasubramanyam M. Novel insights of elevated systemic levels of bisphenol-A (BPA) linked to poor glycemic control, accelerated cellular senescence and insulin resistance in patients with type 2 diabetes. Mol Cell Biochem. (2019) 458:171-83. doi: 10.1007/s11010-019-03540-9

28. Takayanagi S, Tokunaga T, Liu X, Okada H, Matsushima A, Shimohigashi Y. Endocrine disruptor bisphenol A strongly binds to human estrogen-related receptor gamma (ERRgamma) with high constitutive activity. Toxicol Lett. (2006) 167:95-105. doi: 10.1016/j.toxlet.2006.08.012

29. Vermeer LM, Gregory E, Winter MK, Mccarson KE, Berman NE. Exposure to bisphenol A exacerbates migraine-like behaviors in a multibehavior model of rat migraine. Toxicol Sci. (2014) 137:416-27. doi: 10.1093/toxsci/kft245

30. Klenke U, Constantin S, Wray S. BPA Directly Decreases GnRH neuronal activity via noncanonical pathway. Endocrinology. (2016) 157:1980-90. doi: 10.1210/en.2015-1924

31. Cipelli R, Harries L, Okuda K, Yoshihara S, Melzer D, Galloway T. Bisphenol A modulates the metabolic regulator oestrogen-related receptor-alpha in T-cells. Reproduction. (2014) 147:419-26. doi: 10.1530/REP-13-0423

32. Cammenga J, Mulloy JC, Berguido FJ, Macgrogan D, Viale A, Nimer $\mathrm{SD}$. Induction of $\mathrm{C} / \mathrm{EBPalpha}$ activity alters gene expression and differentiation of human CD34+ cells. Blood. (2003) 101:2206-14. doi: 10.1182/blood-2002-05-1546

33. Lei B, Peng W, Xu G, Wu M, Wen Y, Xu J, et al. Activation of G proteincoupled receptor 30 by thiodiphenol promotes proliferation of estrogen receptor alpha-positive breast cancer cells. Chemosphere. (2017) 169:204-11. doi: 10.1016/j.chemosphere.2016.11.066
34. Huang B, Luo $\mathrm{N}$, Wu X, Xu Z, Wang X, Pan X. The modulatory role of low concentrations of bisphenol A on tamoxifen-induced proliferation and apoptosis in breast cancer cells. Environ Sci Pollut Res Int. (2019) 26:2353-62. doi: $10.1007 /$ s1 1356-018-3780-6

35. Schafer TE, Lapp CA, Hanes CM, Lewis JB, Wataha JC, Schuster GS. Estrogenicity of bisphenol A and bisphenol A dimethacrylate in vitro. J Biomed Mater Res. (1999) 45:192-7. doi: 10.1002/(SICI)10974636(19990605)45:3\&lt;192::AID-JBM5\&gt;3.0.CO;2-A

36. Ahbab MA, Barlas N, Karabulut G. The toxicological effects of bisphenol A and octylphenol on the reproductive system of prepubertal male rats. Toxicol Ind Health. (2017) 33:133-46. doi: 10.1177/0748233715603847

37. Chen L, Zhao Y, Li L, Xie L, Chen X, Liu J, et al. Bisphenol A stimulates differentiation of rat stem Leydig cells in vivo and in vitro. Mol Cell Endocrinol. (2018) 474:158-67. doi: 10.1016/j.mce.2018.03.003

38. Skakkebaek NE, Rajpert-De Meyts E, Jorgensen N, Carlsen E, Petersen PM, Giwercman A, et al. Germ cell cancer and disorders of spermatogenesis: an environmental connection? APMIS. (1998) 106:3-11. doi: 10.1111/j.1699-0463.1998.tb01314.x

39. Scinicariello F, Buser MC. Serum testosterone concentrations and urinary bisphenol A, Benzophenone-3, Triclosan, and paraben levels in male and female children and adolescents: NHANES 2011-2012. Environ Health Perspect. (2016) 124:1898-904. doi: 10.1289/EHP150

40. Wang Z, Li D, Miao M, Liang H, Chen J, Zhou Z, et al. Urine bisphenol A and pubertal development in boys. Int J Hyg Environ Health. (2017) 220:43-50. doi: 10.1016/j.ijheh.2016.10.004

41. Eladak S, Grisin T, Moison D, Guerquin MJ, N’tumba-Byn T, Pozzi-Gaudin $\mathrm{S}$, et al. A new chapter in the bisphenol A story: bisphenol S and bisphenol F are not safe alternatives to this compound. Fertil Steril. (2015) 103:11-21. doi: 10.1016/j.fertnstert.2014.11.005

42. Pawlicki P, Duliban M, Tuz R, Ptak A, Milon A, Gorowska-Wojtowicz E, et al. Do G-protein coupled estrogen receptor and bisphenol A analogs influence on Leydig cell epigenetic regulation in immature boar testis ex vivo? Anim Reprod Sci. (2019) 207:21-35. doi: 10.1016/j.anireprosci.2019.06.006

43. Perez-Albaladejo E, Fernandes D, Lacorte S, Porte C. Comparative toxicity, oxidative stress and endocrine disruption potential of plasticizers in JEG-3 human placental cells. Toxicol In Vitro. (2017) 38:41-8. doi: 10.1016/j.tiv.2016.11.003

44. Bjornstrom L, Sjoberg M. Mechanisms of estrogen receptor signaling: convergence of genomic and nongenomic actions on target genes. $\mathrm{Mol}$ Endocrinol. (2005) 19:833-42. doi: 10.1210/me.2004-0486

45. Sharpe RM. The roles of oestrogen in the male. Trends Endocrinol Metab. (1998) 9:371-7. doi: 10.1016/S1043-2760(98)00089-7

46. Couse JF, Hewitt SC, Bunch DO, Sar M, Walker VR, Davis BJ, et al. Postnatal sex reversal of the ovaries in mice lacking estrogen receptors alpha and beta. Science. (1999) 286:2328-31. doi: 10.1126/science.286.5448.2328

47. Lazari MF, Lucas TF, Yasuhara F, Gomes GR, Siu ER, Royer C, et al. Estrogen receptors and function in the male reproductive system. Arq Bras Endocrinol Metabol. (2009) 53:923-33. doi: 10.1590/S0004-27302009000 800005

48. Hamilton KJ, Hewitt SC, Arao Y, Korach KS. Estrogen hormone biology. Curr Top Dev Biol. (2017) 125:109-46. doi: 10.1016/bs.ctdb.2016.12.005

49. Giguere V, Yang N, Segui P, Evans RM. Identification of a new class of steroid hormone receptors. Nature. (1988) 331:91-4. doi: 10.1038/331091a0

50. Huss JM, Garbacz WG, Xie W. Constitutive activities of estrogenrelated receptors: transcriptional regulation of metabolism by the ERR pathways in health and disease. Biochim Biophys Acta. (2015) 1852:1912-27. doi: 10.1016/j.bbadis.2015.06.016

51. Gearhart MD, Holmbeck SM, Evans RM, Dyson HJ, Wright PE. Monomeric complex of human orphan estrogen related receptor-2 with DNA: a pseudodimer interface mediates extended half-site recognition. J Mol Biol. (2003) 327:819-32. doi: 10.1016/S0022-2836(03)00183-9

52. Vanacker JM, Pettersson K, Gustafsson JA, Laudet V. Transcriptional targets shared by estrogen receptor- related receptors (ERRs) and estrogen receptor (ER) alpha, but not by ERbeta. EMBO J. (1999) 18:4270-9. doi: 10.1093/emboj/18.15.4270

53. Filardo EJ, Quinn JA, Bland KI, Frackelton AR Jr. Estrogen-induced activation of Erk-1 and Erk-2 requires the G protein-coupled receptor homolog, GPR30, and occurs via trans-activation of the epidermal growth 
factor receptor through release of HB-EGF. Mol Endocrinol. (2000) 14:164960. doi: $10.1210 /$ mend.14.10.0532

54. Thomas P, Pang Y, Filardo EJ, Dong J. Identity of an estrogen membrane receptor coupled to a $\mathrm{G}$ protein in human breast cancer cells. Endocrinology. (2005) 146:624-32. doi: 10.1210/en.2004-1064

55. Filardo EJ, Quinn JA, Frackelton ARJr, Bland KI. Estrogen action via the G protein-coupled receptor, GPR30: stimulation of adenylyl cyclase and cAMP-mediated attenuation of the epidermal growth factor receptor-to-MAPK signaling axis. Mol Endocrinol. (2002) 16:70-84. doi: $10.1210 /$ mend.16.1.0758

56. Kanda N, Watanabe S. 17beta-estradiol stimulates the growth of human keratinocytes by inducing cyclin D2 expression. J Invest Dermatol. (2004) 123:319-28. doi: 10.1111/j.0022-202X.2004.12645.x

57. Zucchetti AE, Barosso IR, Boaglio AC, Basiglio CL, Miszczuk G, Larocca MC, et al. G-protein-coupled receptor 30/adenylyl cyclase/protein kinase A pathway is involved in estradiol 17ss-D-glucuronide-induced cholestasis. Hepatology. (2014) 59:1016-29. doi: 10.1002/hep.26752

58. Petrie WK, Dennis MK, Hu C, Dai D, Arterburn JB, Smith HO, et al. G protein-coupled estrogen receptor-selective ligands modulate endometrial tumor growth. Obstet Gynecol Int. (2013) 2013:472720. doi: 10.1155/2013/472720

59. Goswami C, Kuhn J, Dina OA, Fernandez-Ballester G, Levine JD, FerrerMontiel A, et al. Estrogen destabilizes microtubules through an ionconductivity-independent TRPV1 pathway. J Neurochem. (2011) 117:9951008. doi: 10.1111/j.1471-4159.2011.07270.x

60. Tica AA, Dun EC, Tica OS, Gao X, Arterburn JB, Brailoiu GC, et al. G protein-coupled estrogen receptor 1-mediated effects in the rat myometrium. Am J Physiol Cell Physiol. (2011) 301:C1262-9. doi: 10.1152/ajpcell.00501.2010

61. Stevant I, Neirijnck Y, Borel C, Escoffier J, Smith LB, Antonarakis $\mathrm{SE}$, et al. Deciphering cell lineage specification during male sex determination with single-cell RNA sequencing. Cell Rep. (2018) 22:1589-99. doi: 10.1016/j.celrep.2018.01.043

62. Bizarro P, Acevedo S, Nino-Cabrera G, Mussali-Galante P, Pasos F, Avila-Costa MR, et al. Ultrastructural modifications in the mitochondrion of mouse Sertoli cells after inhalation of lead, cadmium or lead-cadmium mixture. Reprod Toxicol. (2003) 17:561-6. doi: 10.1016/S0890-6238(03)00096-0

63. Schmahl J, Kim Y, Colvin JS, Ornitz DM, Capel B. Fgf9 induces proliferation and nuclear localization of FGFR2 in Sertoli precursors during male sex determination. Development. (2004) 131:3627-36. doi: 10.1242/dev.01239

64. Kerr JB, Knell CM. The fate of fetal Leydig cells during the development of the fetal and postnatal rat testis. Development. (1988) 103:535-44.

65. Shima Y, Matsuzaki S, Miyabayashi K, Otake H, Baba T, Kato $S$, et al. Fetal leydig cells persist as an androgen-independent subpopulation in the postnatal testis. Mol Endocrinol. (2015) 29:1581-93. doi: 10.1210/me.2015-1200

66. Ge RS, Hardy MP. Variation in the end products of androgen biosynthesis and metabolism during postnatal differentiation of rat Leydig cells. Endocrinology. (1998) 139:3787-95. doi: 10.1210/endo.139.9.6183

67. Nielsen M, Bjornsdottir S, Hoyer PE, Byskov AG. Ontogeny of oestrogen receptor alpha in gonads and sex ducts of fetal and newborn mice. J Reprod Fertil. (2000) 118:195-204. doi: 10.1530/jrf.0.1180195

68. Fisher JS, Millar MR, Majdic G, Saunders PT, Fraser HM, Sharpe RM. Immunolocalisation of oestrogen receptor-alpha within the testis and excurrent ducts of the rat and marmoset monkey from perinatal life to adulthood. J Endocrinol. (1997) 153:485-95. doi: 10.1677/joe.0.1530485

69. Strauss L, Kallio J, Desai N, Pakarinen P, Miettinen T, Gylling H, et al. Increased exposure to estrogens disturbs maturation, steroidogenesis, and cholesterol homeostasis via estrogen receptor alpha in adult mouse Leydig cells. Endocrinology. (2009) 150:2865-72. doi: 10.1210/en.2008-1311

70. Pelletier G, Labrie C, Labrie F. Localization of oestrogen receptor alpha, oestrogen receptor beta and androgen receptors in the rat reproductive organs. J Endocrinol. (2000) 165:359-70. doi: 10.1677/joe.0.1650359

71. Saunders PT, Fisher JS, Sharpe RM, Millar MR. Expression of oestrogen receptor beta (ER beta) occurs in multiple cell types, including some germ cells, in the rat testis. J Endocrinol. (1998) 156:R13-17. doi: $10.1677 /$ joe.0.156r013
72. Rosenfeld CS, Ganjam VK, Taylor JA, Yuan X, Stiehr JR, Hardy MP, et al. Transcription and translation of estrogen receptor-beta in the male reproductive tract of estrogen receptor-alpha knock-out and wild-type mice. Endocrinology. (1998) 139:2982-7. doi: 10.1210/endo.139.6.6028

73. Vaucher L, Funaro MG, Mehta A, Mielnik A, Bolyakov A, Prossnitz ER, et al. Activation of GPER-1 estradiol receptor downregulates production of testosterone in isolated rat Leydig cells and adult human testis. PLoS ONE. (2014) 9:e92425. doi: 10.1371/journal.pone.0092425

74. Shapiro E, Huang H, Masch RJ, Mcfadden DE, Wu XR, Ostrer H. Immunolocalization of androgen receptor and estrogen receptors alpha and beta in human fetal testis and epididymis. J Urol. (2005) 174:1695-8; discussion 1698. doi: 10.1097/01.ju.0000179540.28209.de

75. Boukari K, Ciampi ML, Guiochon-Mantel A, Young J, Lombes M, Meduri G. Human fetal testis: source of estrogen and target of estrogen action. Hum Reprod. (2007) 22:1885-92. doi: 10.1093/humrep/dem091

76. Pelletier G, El-Alfy M. Immunocytochemical localization of estrogen receptors alpha and beta in the human reproductive organs. J Clin Endocrinol Metab. (2000) 85:4835-40. doi: 10.1210/jcem.85.12.7029

77. Fietz D, Ratzenbock C, Hartmann K, Raabe O, Kliesch S, Weidner W, et al. Expression pattern of estrogen receptors alpha and beta and G-proteincoupled estrogen receptor 1 in the human testis. Histochem Cell Biol. (2014) 142:421-32. doi: 10.1007/s00418-014-1216-Z

78. Andersson S, Sundberg M, Pristovsek N, Ibrahim A, Jonsson P, Katona $B$, et al. Insufficient antibody validation challenges oestrogen receptor beta research. Nat Commun. (2017) 8:15840. doi: 10.1038/ncomms 15840

79. Kotula-Balak M, Milon A, Pawlicki P, Opydo-Chanek M, Pacwa A, Lesniak K, et al. Insights into the role of estrogen-related receptors alpha, beta and gamma in tumor Leydig cells. Tissue Cell. (2018) 52:78-91. doi: 10.1016/j.tice.2018.04.003

80. Akingbemi BT, Ge R, Rosenfeld CS, Newton LG, Hardy DO, Catterall $\mathrm{JF}$, et al. Estrogen receptor-alpha gene deficiency enhances androgen biosynthesis in the mouse Leydig cell. Endocrinology. (2003) 144:84-93. doi: 10.1210/en.2002-220292

81. Gould ML, Hurst PR, Nicholson HD. The effects of oestrogen receptors alpha and beta on testicular cell number and steroidogenesis in mice. Reproduction. (2007) 134:271-9. doi: 10.1530/REP-07-0025

82. Saez JM, Benahmed M, Reventos J, Bommelaer MC, Monbrial C, Haour F. Hormonal regulation of pig Leydig cells in culture. J Steroid Biochem. (1983) 19:375-84. doi: 10.1016/S0022-4731(83)80050-8

83. Zhang YF, Yuan KM, Liang Y, Chu YH, Lian QQ, Ge YF, et al. Alterations of gene profiles in Leydig-cell-regenerating adult rat testis after ethane dimethane sulfonate-treatment. Asian J Androl. (2015) 17:253-60. doi: 10.4103/1008-682X.136447

84. Laurich VM, Trbovich AM, O'neill FH, Houk CP, Sluss PM, Payne $\mathrm{AH}$, et al. Mullerian inhibiting substance blocks the protein kinase Ainduced expression of cytochrome p450 17alpha-hydroxylase/C(17-20) lyase mRNA in a mouse Leydig cell line independent of cAMP responsive element binding protein phosphorylation. Endocrinology. (2002) 143:335160. doi: 10.1210/en.2001-211352

85. Stocco DM. StARTing to understand cholesterol transfer. Nat Struct Biol. (2000) 7:445-7. doi: 10.1038/75834

86. Stocco DM. StAR protein and the regulation of steroid hormone biosynthesis. Annu Rev Physiol. (2001) 63:193-213. doi: 10.1146/annurev.physiol.63.1.193

87. Chung JY, Chen H, Midzak A, Burnett AL, Papadopoulos V, Zirkin BR. Drug ligand-induced activation of translocator protein (TSPO) stimulates steroid production by aged brown Norway rat Leydig cells. Endocrinology. (2013) 154:2156-65. doi: 10.1210/en.2012-2226

88. Mast N, Annalora AJ, Lodowski DT, Palczewski K, Stout CD, Pikuleva IA. Structural basis for three-step sequential catalysis by the cholesterol side chain cleavage enzyme CYP11A1. J Biol Chem. (2010) 286:5607-13. doi: 10.1074/jbc.M110.188433

89. Wen Q, Cheng CY, Liu YX. Development, function and fate of fetal Leydig cells. Semin Cell Dev Biol. (2016) 59:89-98. doi: $10.1016 /$ j.semcdb.2016.03.003

90. Zimmermann S, Steding G, Emmen JM, Brinkmann AO, Nayernia $\mathrm{K}$, Holstein $\mathrm{AF}$, et al. Targeted disruption of the Insl3 gene 
causes bilateral cryptorchidism. Mol Endocrinol. (1999) 13:681-91. doi: 10.1210/mend.13.5.0272

91. Nef S, Parada LF. Cryptorchidism in mice mutant for Insl3. Nat Genet. (1999) 22:295-9. doi: 10.1038/10364

92. Kaftanovskaya EM, Feng S, Huang Z, Tan Y, Barbara AM, Kaur S, et al. Suppression of insulin-like3 receptor reveals the role of beta-catenin and Notch signaling in gubernaculum development. Mol Endocrinol. (2011) 25:170-83. doi: 10.1210/me.2010-0330

93. Anand-Ivell R, Wohlgemuth J, Haren MT, Hope PJ, Hatzinikolas G, Wittert G, et al. Peripheral INSL3 concentrations decline with age in a large population of Australian men. Int J Androl. (2006) 29:618-26. doi: $10.1111 /$ j.1365-2605.2006.00714.x

94. Anand-Ivell R, Ivell R. Insulin-like factor 3 as a monitor of endocrine disruption. Reproduction. (2014) 147:R87-95. doi: 10.1530/REP-13-0486

95. Rochester JR, Bolden AL. Bisphenol S and F: a systematic review and comparison of the hormonal activity of bisphenol A substitutes. Environ Health Perspect. (2015) 123:643-50. doi: 10.1289/ehp.1408989

96. Leffers H, Naesby M, Vendelbo B, Skakkebaek NE, Jorgensen M. Oestrogenic potencies of Zeranol, oestradiol, diethylstilboestrol, Bisphenol-A and genistein: implications for exposure assessment of potential endocrine disrupters. Hum Reprod. (2001) 16:1037-45. doi: 10.1093/humrep/16.5.1037

97. Nguyen TMD, Klett D, Combarnous Y. Estrogenic compounds or adiponectin inhibit cyclic AMP response to human luteinizing hormone in mouse leydig tumor cells. Biology. (2019) 8:45. doi: 10.3390/biology8020045

98. Matsushima A, Kakuta Y, Teramoto T, Koshiba T, Liu X, Okada H, et al. Structural evidence for endocrine disruptor bisphenol A binding to human nuclear receptor ERR gamma. J Biochem. (2007) 142:517-24. doi: $10.1093 / \mathrm{jb} / \mathrm{mvm} 158$

99. Park E, Kumar S, Lee B, Kim KJ, Seo JE, Choi HS, et al. Estrogen receptor-related receptor gamma regulates testicular steroidogenesis through direct and indirect regulation of steroidogenic gene expression. Mol Cell Endocrinol. (2017) 452:15-24. doi: 10.1016/j.mce.2017.05.002

100. Ye L, Zhao B, Hu G, Chu Y, Ge RS. Inhibition of human and rat testicular steroidogenic enzyme activities by bisphenol A. Toxicol Lett. (2011) 207:13742. doi: 10.1016/j.toxlet.2011.09.001

101. Ge R-S, Dong Q, Niu E-M, Sottas CM, Hardy DO, Catterall JF, et al. 11 $\beta$ Hydroxysteroid dehydrogenase 2 in rat Leydig cells: its role in blunting glucocorticoid action at physiological levels of substrate. Endocrinology. (2005) 146:2657-64. doi: 10.1210/en.2005-0046

102. Hardy MP, Gao HB, Dong Q, Ge R, Wang Q, Chai WR, et al. Stress hormone and male reproductive function. Cell Tissue Res. (2005) 322:147-53. doi: 10.1007/s00441-005-0006-2

103. Guo J, Yuan X, Qiu L, Zhu W, Wang C, Hu G, et al. Inhibition of human and rat 11beta-hydroxysteroid dehydrogenases activities by bisphenol A. Toxicol Lett. (2012) 215:126-30. doi: 10.1016/j.toxlet.2012.10.002

104. De Gendt K, Atanassova N, Tan KA, De Franca LR, Parreira GG, Mckinnell C, et al. Development and function of the adult generation of Leydig cells in mice with Sertoli cell-selective or total ablation of the androgen receptor. Endocrinology. (2005) 146:4117-26. doi: 10.1210/en.2005-0300

105. O’hara L, Mcinnes K, Simitsidellis I, Morgan S, Atanassova N, SlowikowskaHilczer J, et al. Autocrine androgen action is essential for Leydig cell maturation and function, and protects against late-onset Leydig cell apoptosis in both mice and men. FASEB J. (2014) 29:894-910. doi: 10.1096/fj.14-255729

106. Scott JE, Blecher SR. Beta-glucuronidase activity is present in the microscopic epididymis of the Tfm/Y mouse. Dev Genet. (1987) 8:11-5. doi: $10.1002 /$ dvg. 1020080103

107. Murphy L, O'shaughnessy PJ. Testicular steroidogenesis in the testicular feminized (Tfm) mouse: loss of 17 alpha-hydroxylase activity. J Endocrinol. (1991) 131:443-9. doi: 10.1677/joe.0.1310443

108. Lee HJ, Chattopadhyay S, Gong EY, Ahn RS, Lee K. Antiandrogenic effects of bisphenol A and nonylphenol on the function of androgen receptor. Toxicol Sci. (2003) 75:40-6. doi: 10.1093/toxsci/kfg150

109. Beattie MC, Chen H, Fan J, Papadopoulos V, Miller P, Zirkin BR. Aging and luteinizing hormone effects on reactive oxygen species production and DNA damage in rat Leydig cells. Biol Reprod. (2013) 88:100. doi: 10.1095/biolreprod.112.107052
110. Chen H, Jin S, Guo J, Kombairaju P, Biswal S, Zirkin BR. Knockout of the transcription factor Nrf2: Effects on testosterone production by aging mouse leydig cells. Mol Cell Endocrinol. (2015) 409:113-20. doi: 10.1016/j.mce.2015.03.013

111. D'cruz SC, Jubendradass R, Mathur PP. Bisphenol A induces oxidative stress and decreases levels of insulin receptor substrate 2 and glucose transporter 8 in rat testis. Reprod Sci. (2012) 19:163-72. doi: 10.1177/1933719111415547

112. El-Beshbishy HA, Aly HA, El-Shafey M. Lipoic acid mitigates bisphenol Ainduced testicular mitochondrial toxicity in rats. Toxicol Ind Health. (2013) 29:875-87. doi: $10.1177 / 0748233712446728$

113. Wang J, Chen C, Jiang Z, Wang M, Jiang H, Zhang X. Protective effect of Cordyceps militaris extract against bisphenol A induced reproductive damage. Syst Biol Reprod Med. (2016) 62:249-57. doi: 10.1080/19396368.2016.1182234

114. Srivastava S, Gupta P. Alteration in apoptotic rate of testicular cells and sperms following administration of Bisphenol A (BPA) in Wistar albino rats. Environ Sci Pollut Res Int. (2018) 25:21635-43. doi: 10.1007/s11356-018-2229-2

115. Gupta C. Reproductive malformation of the male offspring following maternal exposure to estrogenic chemicals. Proc Soc Exp Biol Med. (2000) 224:61-8. doi: 10.1046/j.1525-1373.2000.22402.x

116. Naciff JM, Hess KA, Overmann GJ, Torontali SM, Carr GJ, Tiesman JP, et al. Gene expression changes induced in the testis by transplacental exposure to high and low doses of 17 \{alpha\}-ethynyl estradiol, genistein, or bisphenol A. Toxicol Sci. (2005) 86:396-416. doi: 10.1093/toxsci/kfi198

117. Horstman KA, Naciff JM, Overmann GJ, Foertsch LM, Richardson BD, Daston GP. Effects of transplacental 17-alpha-Ethynyl estradiol or bisphenol A on the developmental profile of steroidogenic acute regulatory protein in the rat testis. Birth Defects Res B Dev Reprod Toxicol. (2012) 95:318-25. doi: 10.1002/bdrb. 21020

118. Kobayashi K, Miyagawa M, Wang RS, Sekiguchi S, Suda M, Honma T. Effects of in utero and lactational exposure to bisphenol A on somatic growth and anogenital distance in F1 rat offspring. Ind Health. (2002) 40:375-81. doi: $10.2486 /$ indhealth. 40.375

119. Howdeshell KL, Furr J, Lambright CR, Wilson VS, Ryan BC, Gray LE Jr. Gestational and lactational exposure to ethinyl estradiol, but not bisphenol A, decreases androgen-dependent reproductive organ weights and epididymal sperm abundance in the male long evans hooded rat. Toxicol Sci. (2008) 102:371-82. doi: 10.1093/toxsci/kfm306

120. Kawai K, Nozaki T, Nishikata H, Aou S, Takii M, Kubo C. Aggressive behavior and serum testosterone concentration during the maturation process of male mice: the effects of fetal exposure to bisphenol A. Environ Health Perspect. (2003) 111:175-8. doi: 10.1289/ehp.5440

121. Dere E, Anderson LM, Huse SM, Spade DJ, Mcdonnell-Clark E, Madnick SJ, et al. Effects of continuous bisphenol A exposure from early gestation on 90day old rat testes function and sperm molecular profiles: A CLARITY-BPA consortium study. Toxicol Appl Pharmacol. (2018) 347:1-9. doi: 10.1016/j.taap.2018.03.021

122. Nanjappa MK, Simon L, Akingbemi BT. The industrial chemical bisphenol A (BPA) interferes with proliferative activity and development of steroidogenic capacity in rat leydig cells. Biol Reprod. (2012) 86:135, 1-12. doi: 10.1095/biolreprod.111.095349

123. Kato H, Furuhashi T, Tanaka M, Katsu Y, Watanabe H, Ohta Y, et al. Effects of bisphenol A given neonatally on reproductive functions of male rats. Reprod Toxicol. (2006) 22:20-9. doi: 10.1016/j.reprotox.2005.10.003

124. Akingbemi BT, Sottas CM, Koulova AI, Klinefelter GR, Hardy MP. Inhibition of testicular steroidogenesis by the xenoestrogen bisphenol A is associated with reduced pituitary luteinizing hormone secretion and decreased steroidogenic enzyme gene expression in rat Leydig cells. Endocrinology. (2004) 145:592-603. doi: 10.1210/en.2003-1174

125. Al-Hiyasat AS, Darmani H, Elbetieha AM. Effects of bisphenol A on adult male mouse fertility. Eur J Oral Sci. (2002) 110:163-7. doi: 10.1034/j.1600-0722.2002.11201.x

126. Takao T, Nanamiya W, Nagano I, Asaba K, Kawabata K, Hashimoto $\mathrm{K}$. Exposure with the environmental estrogen bisphenol A disrupts the male reproductive tract in young mice. Life Sci. (1999) 65:2351-7. doi: 10.1016/S0024-3205(99)00502-0 
127. Nakamura D, Yanagiba Y, Duan Z, Ito Y, Okamura A, Asaeda N, et al. Bisphenol A may cause testosterone reduction by adversely affecting both testis and pituitary systems similar to estradiol. Toxicol Lett. (2010) 194:1625. doi: 10.1016/j.toxlet.2010.02.002

128. Tohei A, Suda S, Taya K, Hashimoto T, Kogo H. Bisphenol A inhibits testicular functions and increases luteinizing hormone secretion in adult male rats. Exp Biol Med. (2001) 226:216-21. doi: 10.1177/153537020122600309

129. Tanaka M, Nakaya S, Katayama M, Leffers H, Nozawa S, Nakazawa R, et al. Effect of prenatal exposure to bisphenol A on the serum testosterone concentration of rats at birth. Hum Exp Toxicol. (2006) 25:369-73. doi: 10.1191/0960327106ht638oa

130. Xi W, Wan HT, Zhao YG, Wong MH, Giesy JP, Wong CK. Effects of perinatal exposure to bisphenol A and di(2-ethylhexyl)-phthalate on gonadal development of male mice. Environ Sci Pollut Res Int. (2011) 19:2515-27. doi: $10.1007 /$ s11356-012-0827-y

131. D'cruz SC, Jubendradass R, Jayakanthan M, Rani SJ, Mathur PP. Bisphenol A impairs insulin signaling and glucose homeostasis and decreases steroidogenesis in rat testis: an in vivo and in silico study. Food Chem Toxicol. (2012) 50:1124-33. doi: 10.1016/j.fct.2011.11.041

132. Gilibili RR, Vogl AW, Chang TK, Bandiera SM. Localization of cytochrome $\mathrm{P} 450$ and related enzymes in adult rat testis and downregulation by estradiol and bisphenol A. Toxicol Sci. (2014) 140:26-39. doi: 10.1093/toxsci/kfu070

133. Fenichel P, Dechaux H, Harthe C, Gal J, Ferrari P, Pacini P, et al. Unconjugated bisphenol A cord blood levels in boys with descended or undescended testes. Hum Reprod. (2012) 27:983-90. doi: 10.1093/humrep/der451

134. Komarowska MD, Hermanowicz A, Czyzewska U, Milewski R, Matuszczak E, Miltyk W, et al. Serum bisphenol A level in boys with cryptorchidism: a step to male infertility? Int J Endocrinol. (2015) 2015:973154. doi: 10.1155/2015/973154

135. Fernandez MF, Arrebola JP, Jimenez-Diaz I, Saenz JM, Molina-Molina JM, Ballesteros $\mathrm{O}$, et al. Bisphenol $\mathrm{A}$ and other phenols in human placenta from children with cryptorchidism or hypospadias. Reprod Toxicol. (2016) 59:89-95. doi: 10.1016/j.reprotox.2015.11.002

136. Miao M, Yuan W, He Y, Zhou Z, Wang J, Gao E, et al. In utero exposure to bisphenol-A and anogenital distance of male offspring. Birth Defects Res Part A Clin Mol Teratol. (2011) 91:867-72. doi: 10.1002/bdra.22845

137. Liu C, Xu X, Zhang Y, Li W, Huo X. Associations between maternal phenolic exposure and cord sex hormones in male newborns. Hum Reprod. (2016) 31:648-56. doi: 10.1093/humrep/dev327

138. Adoamnei E, Mendiola J, Vela-Soria F, Fernandez MF, Olea N, Jorgensen $\mathrm{N}$, et al. Urinary bisphenol A concentrations are associated with reproductive parameters in young men. Environ Res. (2018) 161:122-8. doi: 10.1016/j.envres.2017.11.002

139. Den Hond E, Tournaye H, De Sutter P, Ombelet W, Baeyens W, Covaci A, et al. Human exposure to endocrine disrupting chemicals and fertility: a casecontrol study in male subfertility patients. Environ Int. (2015) 84:154-60. doi: 10.1016/j.envint.2015.07.017

140. Meeker JD, Calafat AM, Hauser R. Urinary bisphenol A concentrations in relation to serum thyroid and reproductive hormone levels in men from an infertility clinic. Environ Sci Technol. (2010) 44:1458-63. doi: $10.1021 /$ es 9028292

141. Mendiola J, Jorgensen N, Andersson AM, Calafat AM, Ye X, Redmon JB, et al. Are environmental levels of bisphenol a associated with reproductive function in fertile men? Environ Health Perspect. (2010) 118:1286-91. doi: 10.1289/ehp.1002037

142. N'tumba-Byn T, Moison D, Lacroix M, Lecureuil C, Lesage L, Prud'homme $\mathrm{SM}$, et al. Differential effects of bisphenol A and diethylstilbestrol on human, rat and mouse fetal leydig cell function. PLoS ONE. (2012) 7:e51579. doi: 10.1371/journal.pone.0051579

143. Ben Maamar M, Lesne L, Desdoits-Lethimonier C, Coiffec I, Lassurguere J, Lavoue V, et al. An investigation of the endocrine-disruptive effects of bisphenol a in human and rat fetal testes. PLOS ONE. (2015) 10:e0117226. doi: 10.1371/journal.pone.0117226

144. Desdoits-Lethimonier C, Lesne L, Gaudriault P, Zalko D, Antignac JP, Deceuninck Y, et al. Parallel assessment of the effects of bisphenol A and several of its analogs on the adult human testis. Hum Reprod. (2017) 32:146573. doi: 10.1093/humrep/dex093

145. Eladak S, Moison D, Guerquin MJ, Matilionyte G, Kilcoyne K, N'tumbaByn T, et al. Effects of environmental bisphenol A exposures on germ cell development and leydig cell function in the human fetal testis. PLoS ONE. (2018) 13:e0191934. doi: 10.1371/journal.pone.0191934

146. Liao C, Kannan K. Concentrations and profiles of bisphenol A and other bisphenol analogues in foodstuffs from the United States and their implications for human exposure. J Agric Food Chem. (2013) 61:4655-62. doi: 10.1021/jf400445n

147. Liao C, Liu F, Guo Y, Moon HB, Nakata H, Wu Q, et al. Occurrence of eight bisphenol analogues in indoor dust from the United States and several Asian countries: implications for human exposure. Environ Sci Technol. (2012) 46:9138-45. doi: 10.1021/es302004w

148. Hu Y, Zhu Q, Yan X, Liao C, Jiang G. Occurrence, fate and risk assessment of BPA and its substituents in wastewater treatment plant: a review. Environ Res. (2019) 178:108732. doi: 10.1016/j.envres.2019.108732

149. Becerra V, Odermatt J. Detection and quantification of traces of bisphenol A and bisphenol S in paper samples using analytical pyrolysis-GC/MS. Analyst. (2012) 137:2250-9. doi: 10.1039/c2an15961a

150. Jin H, Xie J, Mao L, Zhao M, Bai X, Wen J, et al. Bisphenol analogue concentrations in human breast milk and their associations with postnatal infant growth. Environ Pollut. (2019) 259:113779. doi: 10.1016/j.envpol.2019.113779

151. Li A, Zhuang T, Shi W, Liang Y, Liao C, Song M, et al. Serum concentration of bisphenol analogues in pregnant women in China. Sci Total Environ. (2019) 707:136100. doi: 10.1016/j.scitotenv.2019.136100

152. Cunha SC, Fernandes JO. Quantification of free and total bisphenol $\mathrm{A}$ and bisphenol $\mathrm{B}$ in human urine by dispersive liquid-liquid microextraction (DLLME) and heart-cutting multidimensional gas chromatography-mass spectrometry (MD-GC/MS). Talanta. (2010) 83:117-25. doi: 10.1016/j.talanta.2010.08.048

153. Roelofs MJ, Van Den Berg M, Bovee TF, Piersma AH, Van Duursen MB. Structural bisphenol analogues differentially target steroidogenesis in murine MA-10 Leydig cells as well as the glucocorticoid receptor. Toxicology. (2015) 329:10-20. doi: 10.1016/j.tox.2015.01.003

154. Pelch KE, Li Y, Perera L, Thayer KA, Korach KS. Characterization of estrogenic and androgenic activities for bisphenol A-like chemicals (BPs): in vitro estrogen and androgen receptors transcriptional activation, gene regulation, and binding profiles. Toxicol Sci. (2019) 172:23-37. doi: $10.1093 /$ toxsci/kfz173

155. Masuya T, Iwamoto M, Liu X, Matsushima A. Discovery of novel oestrogen receptor alpha agonists and antagonists by screening a revisited privileged structure moiety for nuclear receptors. Sci Rep. (2019) 9:9954. doi: 10.1038/s41598-019-46272-y

156. Keminer $\mathrm{O}$, Teigeler $\mathrm{M}$, Kohler $\mathrm{M}$, Wenzel A, Arning J, Kassner $\mathrm{F}$, et al. A tiered high-throughput screening approach for evaluation of estrogen and androgen receptor modulation by environmentally relevant bisphenol A substitutes. Sci Total Environ. (2019) 717:134743. doi: 10.1016/j.scitotenv.2019.134743

157. Fang $H$, Tong W, Branham WS, Moland CL, Dial SL, Hong H, et al. Study of 202 natural, synthetic, and environmental chemicals for binding to the androgen receptor. Chem Res Toxicol. (2003) 16:1338-58. doi: $10.1021 /$ tx030011g

158. Hong H, Branham WS, Ng HW, Moland CL, Dial SL, Fang H, et al. Human sex hormone-binding globulin binding affinities of 125 structurally diverse chemicals and comparison with their binding to androgen receptor, estrogen receptor, and alpha-fetoprotein. Toxicol Sci. (2015) 143:333-48. doi: 10.1093/toxsci/kfu231

159. Kitamura S, Suzuki T, Sanoh S, Kohta R, Jinno N, Sugihara K, et al. Comparative study of the endocrine-disrupting activity of bisphenol A and 19 related compounds. Toxicol Sci. (2005) 84:249-59. doi: 10.1093/toxsci/kfi074

160. Goldinger DM, Demierre AL, Zoller O, Rupp H, Reinhard H, Magnin $\mathrm{R}$, et al. Endocrine activity of alternatives to BPA found in thermal paper in Switzerland. Regul Toxicol Pharmacol. (2015) 71:453-62. doi: 10.1016/j.yrtph.2015.01.002 
161. Matsushima A, Liu X, Okada H, Shimohigashi M, Shimohigashi Y. Bisphenol $\mathrm{AF}$ is a full agonist for the estrogen receptor ERalpha but a highly specific antagonist for ERbeta. Environ Health Perspect. (2010) 118:1267-72. doi: 10.1289/ehp.0901819

162. Feng Y, Shi J, Jiao Z, Duan H, Shao B. Mechanism of bisphenol AF-induced progesterone inhibition in human chorionic gonadotrophin-stimulated mouse Leydig tumor cell line (mLTC-1) cells. Environ Toxicol. (2018) 33:670-8. doi: 10.1002/tox.22554

163. Furr JR, Lambright CS, Wilson VS, Foster PM, Gray LEJr. A shortterm in vivo screen using fetal testosterone production, a key event in the phthalate adverse outcome pathway, to predict disruption of sexual differentiation. Toxicol Sci. (2014) 140:403-24. doi: 10.1093/toxsci/ kfu081

164. Ullah A, Pirzada M, Jahan S, Ullah H, Razak S, Rauf N, et al. Prenatal BPA and its analogs BPB, BPF, and BPS exposure and reproductive axis function in the male offspring of Sprague Dawley rats. Hum Exp Toxicol. (2019) 38:1344-65. doi: 10.1177/0960327119862335

165. Ullah A, Pirzada M, Jahan S, Ullah H, Shaheen G, Rehman H, et al. Bisphenol $\mathrm{A}$ and its analogs bisphenol B, bisphenol $\mathrm{F}$, and bisphenol S: Comparative in vitro and in vivo studies on the sperms and testicular tissues of rats. Chemosphere. (2018) 209:508-16. doi: 10.1016/j.chemosphere.2018.06.089

166. Ullah A, Pirzada M, Jahan S, Ullah H, Turi N, Ullah W, et al. Impact of low-dose chronic exposure to bisphenol A and its analogue bisphenol B, bisphenol $\mathrm{F}$ and bisphenol S on hypothalamo-pituitary-testicular activities in adult rats: A focus on the possible hormonal mode of action. Food Chem Toxicol. (2018) 121:24-36. doi: 10.1016/j.fct.2018.08.024

Conflict of Interest: The authors declare that the research was conducted in the absence of any commercial or financial relationships that could be construed as a potential conflict of interest.

Copyright (๐) $2020 \mathrm{Li}$, Wen, Wang, Mo, Zhong and Ge. This is an open-access article distributed under the terms of the Creative Commons Attribution License (CC BY). The use, distribution or reproduction in other forums is permitted, provided the original author(s) and the copyright owner(s) are credited and that the original publication in this journal is cited, in accordance with accepted academic practice. No use, distribution or reproduction is permitted which does not comply with these terms. 